\title{
CORPORATE SOCIAL RESPONSIBILITY AS KEY CRITERIA FOR INVESTMENT OF PENSION FUNDS IN CROATIA*
}

\author{
Martin Sopta1 \& Martina Sopta ${ }^{2}$
}

UDC / UDK: 336.714(497.5)

$338.914(497.5)$

JEL classification / JEL klasifikacija: G23

DOI: https://doi.org/10.22598/pi-be/2017.11.1.91

Review / Pregledni rad

Received / Primljeno: August 29, 2016 / 29. kolovoza 2016.

Accepted for bublishing / Prihvaćeno za tisak: May 31, 2017 / 31. svibnja 2017.

\section{Summary}

Fierce changes in the labor department, the pressure to achieve higher flexibility and deregulation of the labor market narrow the base and coverage for retirement insurance. Longer periods of unemployment and work pursuit are already almost a rule, rather than exception, and as new technologies lower the need for real workers, it is easy to imagine the reality where economic growth will not necessarily be positively correlated with the growth on the labor market. In those conditions, the need for social solidarity and government social responsibility should be higher. Corporate social responsibility, especially the area of employee rights, serves as guidance for further growth and development of the company, at the same time taking into account the social, ecological and other components. While completing the process, one must not forget fulfilling the needs of not only the employees, but also the needs of the shareholders that will surely endorse the growth of the company, as well as the correlated increase in the value of the share that is directly stimulated by the phenomenon of corporate social responsibility. This paper elaborates on the possibility of including corporate social responsibility in the decision-making criteria when mandatory pension funds consider investing in Croatia. Within current market opportunities, those pension funds are becoming majority owners of large joint-stock companies, which creates the possibility of their crucial influence as big market protagonists in decision-making related with corporate social responsibility. This paper gives some examples from practices of pension funds in developed countries, as well as ways of including corporate social responsibility in the main flows of how joint-stock companies are run.

Key words: Croatia, investment of pension funds, corporate social responsibility.

\footnotetext{
* The paper was presented at the first international conference "Business \& Entrepreneurial Economics" (BEE - 2016), 18 - 20th of May 2016, which was organised by the Students'Business Incubator at the University of Zagreb and the Faculty of Economics and Business, University of Zagreb, Croatia.

1 Martin Sopta, M.Sc., Croatia, E-mail: martin.sopta@a3-doo.hr

2 Martina Sopta, Ph.D., Assistant Professor, Faculty of Economics and Business, University of Zagreb, Croatia, E-mail: msopta@efzg.hr
} 


\section{INTRODUCTION}

In new economic opportunities, changes of the economic paradigm have been spotted that no longer have the exclusive purpose of maximizing profits. Apart from maximizing the firm's value and other goals, they impose new solutions in terms of corporate social responsibility. In line with these trends, the way of governing pension funds is studies, and this could point out to changes in the policy making of firms or joint-stock companies.

In developed markets, pension funds are the carriers of activity, innovation and liquidity on the capital markets Therefore they are, alongside banks, the most significant subjects of financial markets. In the American market only, public pension funds, with over trillion US dollars of capital, have become the cardinal force in private sector investments in the ownership structure of corporations, i.e. joint-stock companies. ${ }^{3} \mathrm{Mem}$ bers of pension funds have ensured incomes as the result of safe returns that these funds have had in the past due to their investments in less cost-effective bonds. The financial stability of the past times brought about the power of pension funds, and now represents the driving force for investment.

On the other hand, according to experts, firms that invest in socially responsible activities have better results marketwise. ${ }^{4}$ Firms or joint-stock companies that implement socially responsible activities become more competitive in the market, and are therefore more attractive for investors like pension funds. Although in Croatia the market capital is not as developed as in other developed countries, apart from financial indicators that are still most important, corporate social responsibility is also gaining importance.

\section{PURPOSE OF DOING BUSINESS IN TERMS OF CORPORATE SOCIAL RESPONSIBILITY}

Originally, the theory of firms was based on the assumption that the intention or the purpose of a company is to maximize its liquid or short-term profits. ${ }^{5}$ Traditionally, microeconomics determines profit, or its variations, as a fundamental objective of doing business, and it is, from the point of view of the intermediary role of the firm, possible to challenge the adequateness of these objectives used commonly to determine value and its modality. ${ }^{6}$ It is, necessary to point out that the natural financial purpose of a company is to maximize its current market value. ${ }^{7}$ However, corporate social responsibility introduces new goals in doing business that are not vitally distinguished from the traditional purpose of doing business.

\footnotetext{
Prakash, Sethi, S.: Investing in Socially Responsible Companies is a Must for Public Pension Funds - Because There is no Better Alternative, Journal of Business Ethics 56: 99-129, 2005.

4 Bird, R. et al.: What Corporate Social Responsibility Activities are Valued by the Market?, Journal of Business Ethics, 76 (2), 2007, p. 204.

Salvatore, D.: Ekonomija za menedžere u svjetskoj privredi, Mate, Zagreb, 1994, p. 11.

6 Orsag, S.: Vrijednosni papiri - investicije i instrumenti financiranja, Revicon, Sarajevo, 2011, p. 129.

7 Brealey R.A., Myers S.C., Marcus, A.J.: Osnove korporativnih financija, Mate d.o.o., Zagreb, 2007,p. 12.
} 
The tasks that managers in key positions should implement are ${ }^{8}$ :

- Continuously explore and apply new, innovative ways of corporate social responsibility;

- Recognize and keep in mind how their activities influence the interests of all stakeholder groups;

- Follow a clear value system that is entangled in the organizational culture and is an unavoidable filter through which all business decisions are made, especially the strategic ones;

- Clearly define the internal communication systems, especially the early warnings systems and encourage employees to take charge in battling irresponsible behavior;

- Encourage responsible behavior through a reward and promotion system;

- Include all employees in creating values and an ethical standard of behavior so that all employees could identify with it.

The competitive balance paradigm was a dominant portrayal of the economic system since Adam Smith until the present day. According to the paradigm, there is an equilibrium between supply and demand that is reached through price adjustment, and individual subjects who are also both owners and managers, primarily react to the price signals. Theoreticians like Walras, Marshall and Jevons have contributed to the development of this paradigm, and at the end of the 19th century have created a neoclassical theory that is taught even today within the microeconomic theory. They are the ones who incorporated marginal analysis and mathematics through which they processed relevant topics. The first ever presentation of general equilibrium was made by Walras who published a highly formalized theory of general equilibrium in 1874 . The modern mathematical version, like the one created by Arrow and Debreu (1954.), was based on Walras' vision.

The fundamental premise of the neoclassical view of firms is portrayed in the statement that the purpose of firms' actions is to maximize profits. In other words, through manufacture of goods, the firm can satisfy the ability to make payments and is not interested in anything other than maximizing profit. The neoclassic firm is in that way oriented to the maximization of profit, or the minimization of costs, since it is offering its product whose price is set, and the firm itself cannot influence the determined prices.

The production of a neoclassical firm is described by the production function that shows the relationship between the product and the production factors. Costs are derived from the production function up to the point where the prices of production factors at the production factors' market are known. The income of a neoclassical firm are derived from the scale of the market demand which shows the number of products

8 Tipurić, D. i suradnici: Korporativno upravljanje, poglavlje OMAZIĆ, M.A: Društvena odgovornost poduzeća i korporativno upravljanje, Sinergija, Zagreb, 2008, p. 356. 
customers want to buy at different prices for a unit of product by a simple multiplication of the quantity of products and price. Since the price is constant, one determinate of income is the quantity of product, as well as the level of costs. The difference between income and costs presents the profit, and a plausible firm strives to determine the quantity of the product at which it maximizes the difference between income and cost, which is its profit.

In other words, the firm will increase its own production as long as the marginal income equals marginal costs. When its equality is achieved, the neoclassical firm maximizes its profits.

In the 1930s, first critics of the neoclassical theory appeared, which caused a growing discontent of the traditional neoclassic theory, as well as its marginalist principle of decision-making. Discontent was multiple, and part of it is described below.

One of the first threats to the neoclassical theory of firms was directed by Hall and Hitch (1939). Until then the principles of Joan Robinson and Edward Chamberlin ${ }^{9}$ were accepted, which claimed that the firm is atomistic, that it neglects the reaction of the competitors, and that through the marginalist principle it maximizes not only the short-term profit, but also the long-term profit. Those theoretical views did not correlate with the empirical findings of Hall and Hitch based on a questionnaire taken on a small sample of firms, working mostly in refining, about how they decide about the quantity of production, and price establishment. It turned out that the most significant discovery of their research was that firms are not aiming at profit maximization by equalizing marginal incomes and marginals costs. The price of the product, however, is determined based on the total costs in which the "normal" profit is included. If by applying this rule, known as cost-plus, a maximal profit is reached, this is accidental.

There are also a few arguments in defense of the orthodox theory - the marginalist principle. The "normal" profit margin does not have to be constant, but variable. Hence, when demand recedes, lower profits are expected, and consequently the price will be lower. Therefore, if the firms do not comply with the marginalist principle, the course of the reaction will be equal. Furthermore, in the absence of perfect information, profit maximization could be accidental. Still, the wisest and the most capable decision makers (managers) who make successful predictions, come closest to the maximization of profit, and consequently to the application of the marginalist principle. Those who do not come close enough will most likely not survive on the market. Although the neoclassical assumption of profit maximization is not something decision makers consciously follow, the defense of the orthodox view, represented by Fritz Machlup, suggests that profit maximization best explains the actions of firms on the market.

However, recent empirical studies confirmed the argument that firms do not behave in a way to achieve profit minimization or value maximization. As Stiglitz (1991) put it: "The most significant examples of firms show that their behavior is determined by taxes or takeovers. Most of the firms, "maybe the majority", do not minimize tax payments, and "a lot of studies showed that firms that have experience with hostile take-

9 Salvatore, D.: Ekonomija za menedžere u svjetskoj privredi, Mate, Zagreb, 1994, p. 24. 
overs do not increase their stock market value". Additionally, among those firms are also main companies that can survive in key industries. This suggest that profit maximization is not the best explanation for company behavior.

It is clear that the activity of corporate social responsibility does not overlap in some parts with the firms' goals. However, the administration will try to coordinate the goals so that the end goal is fulfilling the interests of the shareholder, and of the employees. However, a balanced relationship with its surroundings and the market on which the firm operates must not be forgotten. The key factor of survival or the existence of the firm on the market must not be forgotten, because if it is brought into question, then the purpose of corporate social responsibility itself is lost.

\subsection{Theoretical framework of corporate social responsibility}

The phenomenon of corporate social responsibility is narrowly connected with the appearance of firms as institutions. By the twentieth century, the firm or the corporation was not a dominant form of business organization. ${ }^{10}$ It was created for a typical narrow, clearly defined purpose such as transoceanic travel, building canals, railroads, colonial commerce, as well as building hospitals, universities and other establishments of public interest. The first companies were created under favorable social assumptions and had an independent legal status of their owners, which was a considerable change in comparison to other forms. Its predecessors were the collective organizations of the middle ages like guilds which were created as a form of protection from the central aristocratic power and an instrument of creating a congregation of wealth. What made those organizations quasi-corporative forms was their existence that was independent of membership and the fact that all of the assets belonged to the organization, not the individual. Such organizations existed earlier, but were not as widespread until the prevalence of the feudal setup. ${ }^{11}$

The predecessors of a modern corporation (company) were organizations incorporated in Great Britain during the rule of Queen Elizabeth I.: The Muscovy Company (1555), the Spanish Company (1577), the East India Company (1601), the Virginia Company of London (1606), which supplemented partnerships and associations typical for larger entrepreneurial activities of that age. ${ }^{12}$ The modern form of companies is outlined in two British laws: the Law of 1844 allowed joint stock companies to define their purpose, which gave them the freedom to start performing profitable activities, and the Law of 1854 enabled the shareholders limited liability - the protection of their assets

${ }^{10}$ Corporation is the official term for joint stock company in the USA. The legal definition of a corporation was given on 2 February 1819. It was when the Supreme Court of the United States of America confirmed that a corporation is protected by the Constitution. - Berk, J., Demarzo, P: Corporate Finance, Pearson International edition Boston, 2007, p. 3.

11 Monks, R.A.G. and Minow, N.: Corporate Governance, 3rd ed. Oxford Blackwell Publishing, p.101., 2003.

12 See source in Tipurić, D.: Nadzorni odbor i korporativno upravljanje, Sinergija, Zagreb, 2006, p. 17. Colley, J.L.Jr., Doyle, J.L.. Logan, G.W. i Stettinius, W.: Corporate Governance, McGraw-Hill, New York, 2003, p. 9. 
from company activity. ${ }^{13}$ Even tough in the other half of the nineteenth century there was some evidence of the growing importance of companies, it is not until the first half of the twentieth century that organizing economic activities in the firm became the dominant form of business activity, with crucial importance on both the global and national level in developed countries. In the United Kingdom, the incorporation of limited liability has been allowed since 1862, in France since 1863, and in Germany since 1884, under the condition of the existence of a mandatory supervisory board which represents and protects the interests of shareholders. ${ }^{14}$

Historically speaking, modern economies were formed in the period from the early sixteenth century to the first decade of the twentieth century. They reached the diversity of companies that commonly classify in a lower or higher number of industries. In Croatia, the joint stock company was defined in the Corporations Act of 1993, in Article 159, in which the joint stock company is defined as a public company in which the members (shareholders) participate in shares in the capital divided into stocks. A joint stock company can only have one owner, while the shareholders are not liable for obligations. ${ }^{15}$

Modern corporations or joint stock companies have expanded the financial risk on a diversified portfolio of millions of individual and institutional investors, and have allowed investors to adjust the risk to their unique circumstances and tendencies. ${ }^{16} /{ }^{17} \mathrm{It}$ was a crucial incentive to accelerate economic growth, especially by exploiting the advantages of scale and extent on a global level. ${ }^{18} \mathrm{~A}$ joint stock company is a network within which the interests of all contributors are accomplished. The rise of the joint stock company overlaps with the need for company enhancement. The joint stock company has also proved efficient in allocating resources, in creating new technologies, products and services and increasing productivity. As a successful and widely accepted institutional arrangement for creating and distributing wealth, the modern concept creates wealth in many different ways: earnings for investors, compensations for employees, cost benefit for customers, and more. Investors, employees, customers and the suppliers contribute resources to the corporation to achieve its own interests.

All this conditions the changes that seek fulfillment of the criteria of corporate social responsibility. With the development of joint stock companies in the middle of the eighteenth century, the first indicators of the postulates of corporate social responsibility appear in terms of housing workers, and the phenomenon continues to develop with the development of companies, which was most thoroughly explored and chrono-

${ }^{13}$ Grant, G. H.: The Evolution of Corporate Governance and its Impact on Modern Corporate America, Management Decision, 41 (9), 2003, p. 923.

${ }_{14}$ Clarke, T.: Theories of Corporate Governance: The Philosophical Foundations of Corporate Governance, London: Routledge, 2004, p. 2.

15 Narodne novine, 111/93, 34/99, 52/00, 118/03 and 107/07.

${ }^{16}$ Jensen, M.C.: Eclipse of Public Corporation, Harvard Business Review, pg. 64-74, 1989.

17 Porter, M.E., Montgomery, C.A.: Strategy: Seeking and Securing Competitive Advantage, Boston: Harvard Business School Press, 1991, p. 427.

18 For example, today one hundred biggest global corporations control a third of the world capital (Grant, G.H. 2003). 
logically described by Omazić in his dissertation. ${ }^{19}$ The awareness of fair and honest business treatment is slowly awakened with the development of the society and the improvement of the quality of living. One cannot function without the other, since those are the necessary assumptions for the growth and development of the company.

Furthermore, it is necessary to point out that deliberations about the phenomenon of corporate social responsibility comes from a theoretic base, just like all other phenomena. By studying different authors who analyzed corporate social responsibility, a whole series of theories have been presented that explain some component of corporate social responsibility. One of them has been systematized by Omazić: ${ }^{20}$

1. Instrumental theories

1.1. Theory of maximizing stockholder value

1.2. Theory focused on strategic goals of achieving competitive advantage

1.3. Theory of causal marketing

2. Political theories

2.1. Corporate constitutionalism

2.2. Integrative theories of social agreement

2.3. Corporative affiliation

3. Integrative theories

3.1. Management of problematic issues

3.2. Principle of public responsibility

3.3. Management of stakeholder groups

3.4. Social performance of the company

4. Ethical theories

4.1. Normative theory of stakeholder group management

4.2. The theory of general law

Even though all theories contribute to creating corporate social responsibility, according to personal discretion it can be concluded that instrumental theories causally set a framework for corporate social responsibility. Other theories direct and shape the reality of corporate social responsibility as regards their role in the society and as regards assuming more responsibility for affecting all of the key stakeholder groups such as customers, employees, shareholders, suppliers, competitors and members of some local communities.

19 Omazić, A. M.: Društvena odgovornost i strategije hrvatskih poduzeća, Doktorska disertacija, Ekonomski fakultet, Sveučilište u Zagreb, 2007, p. 70 - 76.

${ }^{20}$ Omazić, A. M.: Društvena odgovornost i strategije hrvatskih poduzeća, Doktorska disertacija, Ekonomski fakultet, Sveučilište u Zagreb, 2007, p. 87 - 128. 


\subsection{Definition and main domains of corporate social responsibility}

There are various ways of defining the main domains of corporate social responsibility. Through defining the domains of corporate social responsibility, many experts and institutions, try to set the principles that should serve as strategic guidelines for a firm or joint stock company. The European Commission defines corporate social responsibility as a concept through which a firm integrates the social concern and concern for the environment into its business decisions, and interacts with stakeholder groups on a voluntary basis. ${ }^{21}$

The World Bank defines corporate social responsibility as a contribution of a firm to ethical conduct and sustainable development through cooperation with stakeholder groups, in order to improve life in a way that is good for business, sustainable growth and the whole society. ${ }^{22}$ The international initiative of the UN named "Global Compact", divides the principles of sustainable growth into four main areas: human rights, workers' rights, environment and suppression of corruption. ${ }^{23}$ Rašić systematically points out the main areas of corporate social responsibility: ${ }^{24}$

- relationship with employees and workers' rights,

- health and safety,

- responsibility toward the community and the society,

- responsibility toward partners,

- responsibility toward customers,

- respect of human rights,

- care for the environment,

- corporate management,

- suppression of corruption.

By analyzing the definitions of the areas of corporate social responsibility by experts and organizations, it can be concluded that the main domains can be defined by the actions of the firm (corporation or joint-stock company) toward factors that present themselves in the scope of its business. Consequently, the areas can be defined, and in some areas, they even overlap:

a) within the relationship between company management and owners:

- corporate management;

- responsibility towards partners

\footnotetext{
${ }^{21}$ Commission of the European Communities: Communication from the Commission concerning corporate social responsibility: A business contribution to sustainable development, COM, 347, 2008, p. 6.

22 World Bank: Economic and Corporate Social Responsibility, European University Institute, 2008, p. 5.

${ }^{23}$ According to Rašić. S., chapter in the book Galetić, L. i suradnici: Organizacija velikih poduzeća, Sinergija, Zagreb, 2011, p. 460.

${ }^{24}$ Galetić, L. i suradnici: Organizacija velikih poduzeća, Sinergija, Zagreb, 2011, p. 461.
} 
b) within the relationship between company management and employees:

- human rights,

- workers' rights,

- health and safety.

c) within the relationship between company and government:

- suppression of corruption,

- ethical behavior.

d) within the relationship between company and society:

- quality of products and services,

- responsibility toward consumers,

- community service or marketing for firms,

- corporate philanthropy.

e) within the relationship between company and its environment:

- environment,

- global management.

Some areas can overlap, but it is important to point out that it is by abiding by the principles of corporate social responsibility that the previously presented relationships are improved.

\subsection{Integration of corporate social responsibility within the management decisions of a business organization}

Based on the explanations of corporate social responsibility presented above, the question arises about the possibility or method of integrating these principles in management decisions of firms or joint stock companies (corporations). Omazić ${ }^{25}$ warns that corporate social responsibility of a firm should not be viewed as a generic determinant of a strategy that is applicable in almost all conditions. Its complexity may make it seem a universally applicable concept, but it has to bear in mind the uniqueness of the moment, cultural determinants and the market regularities. This means that social corporate responsibility reflects equally the strengths and the weaknesses of a market economy and capitalism. Therefore, it is important to decide how to integrate individual components of corporate social responsibility within the process of decision making by the management.

For most authors who deal with problems of organization and management, decision-making is the basis of management. Management connects all elements of the organization in a consistent unity, allowing the organization to function and live. ${ }^{26}$

${ }^{25}$ Tipurić, D. i suradnici: Korporativno upravljanje, Sinergija, Zagreb, 2008,p. 340

${ }^{26}$ Sikavica, P.: Organizacija, Školska knjiga, Zagreb, 2011, p. 616. 
The function and life of an organization must not be in any way jeopardized, not even by applying the principle of corporate social responsibility, because otherwise there will be no business organization within which it could be applied.

As has already been pointed out, it is necessary to harmonize the business goals with the tasks of corporate social responsibility. It is not possible to guarantee in practice that corporate social responsibility will always be more profitable for the company, but this is not even necessary. However, when one of the company's main purpose is threatened, in this case the survival of the firm, then the protection of the firm's interests is raised, notwithstanding the way those decisions strategically position the firm or the joint stock company itself.

\subsection{Motives for introducing corporate social responsibility}

Reasons for inducting corporate social responsibility can be differentiated into two groups: altruistic motives and economic motives. ${ }^{27}$ Altruistic motives involve the need of a firm or a society to do right according to right value principles. It also involves the ethical component of doing business.

Business ethics within corporate social responsibility is a basis for doing business. This implies the acceptance of the principles and the code prescribed by the corporation itself or by some government institution (for example the Croatian Chamber of Economy). The ethical responsibility should be brought into connection with the participants of the entire business process.

Economic motives are basically connected with the maximization of profits, as well as with the maximization of the value of the firm. However, the motive of the survival of the firm must not be forgotten. In operational terms, these motives can be divided into specialized sub motives such as: financial independence, increase in productivity, higher efficiency, higher bargaining power of the firm, competitiveness, making a marketing image, higher satisfaction of the end consumer, employee motivation, etc.

The application of principles of corporate social responsibility will depend on the decisions of applying a business strategy and on the strategic positioning of the firm. The motives can justify the management's actions before the owners, the market, and the public.

\section{KEY ELEMENTS OF INVESTMENTS OF CROATIAN PENSION FUNDS}

There is no universal recipe for a "healthy" pension system that is resistant to demographic oscillations, macroeconomic consequences of an aging population, unfavorable movement on the labor marker, manipulative influences of the public authorities, no matter whether it is public or private, capitalized or a system of current distribution.

${ }_{27}$ Rašić, S: Galetić, L. i suradnici: Organizacija velikih poduzeća, Sinergija, Zagreb, 2011, p. 462. 
The task is to form a retirement system that insures safe and steady incomes for the elderly, regardless of the differences between applied shapes or its combinations. A serious and argued social dialogue is a necessary precondition for high-quality solutions in shaping and adjusting the retirement system to new circumstances, in order to ensure its financial longevity with appropriate pension benefits. It is necessary to establish a socially acceptable equilibrium between these two goals. It can be accomplished by planned and systematic work along with the simulation of the consequences of the accepted solutions, with all interested parties involved. The area of social security at an old age is an area of human rights of the second generation, and at the same time a determinant of the civilization of a community. Aging is our fate, even though the optimism of youth does not recognize it. The fact is that fierce changes in the labor market, the pressure for higher flexibility and labor market deregulation will lower the base and the coverage of pension insurance.

Longer periods of unemployment and work pursuit are already almost a rule rather than an exception, and new technologies lower the need for real workers. It is easy to imagine the reality where economic growth will not necessarily be positively correlated with the growth of the labor market. In these conditions, the need for social solidarity and government responsibility (public finance) will be higher. In order to analyze the investments of Croatian pension funds, it is necessary to study best practices of other countries.

As it has been pointed out at the beginning of the chapter, after the retirement reform was carried out in Croatia in 2002, and after the establishment of a new system of individualized capitalized savings, up until today the pension funds gathered over 12 billion HRK (about 1.6 billion EUR) in the so-called $2^{\text {nd }}$ and $3^{\text {rd }}$ pillar. Therefore, they became important participants on the market. Demand and channeling the demand of pension funds is an exceptionally important component of the overall development of the Croatian market. The modus of their regulation is significant.

In scientific literature there is a substantial amount of papers which study the contribution of investment and pension funds. The authors have mostly dealt with portfolio management and the omnipresent dilemma: whether to take the active or the passive approach, i.e. whether or not an active fund management can ensure higher contribution than simple investment into indexes. Many authors such as Jensen, Daniel, Grinblatt, Titman, Wermers, Blake, Timmermann established that there is no evidence that active management could bring over average contributions, especially not in a longer period of time. Ippolito, Turner, Lakonishok, Shleifer, Vishney have determined that fund managers have significantly lower yields than those of the S\&P 500 Index. Nevertheless, there are authors like I. Tonks, who claim that fund managers use an active approach to achieve better yields than the index growth, over a longer period. ${ }^{28}$

Other than the dilemma of active or passive management, the next big group of research deals with determining the way of measuring the work results of pension funds. At the start of the investment cycle, the pension funds usually set their investment goals that depend on a series of factors such as the age structure of the members,

${ }^{28}$ By Ian Tonks: "Fund Manager Performance of Segregated UK Pension Funds", CMPO, Working Paper Series No. 01/33, University of Bristol. 
risk preference, desired contribution, and so on. In accordance with the determined investment goals, the strategic allocation of funds is determined based on the basic classes of assets, while the results (achieved yields) of every class are compared to a defined benchmark, i.e. indexes for each asset class, such as S\&P 500 for shares, Lehman Brothers' Government/Corporate Index for bonds, Lehman Brothers' Three-Month Treasury Bill Index for the money market instruments etc. ${ }^{29}$

To be more specific, WM Company, one of the two providers of performance measurement services in Great Britain (the other one is CAPS - "Combined Actuarial Performance Services"), uses the following set of benchmarks for individual classes of assets in which pension funds invest: ${ }^{30}$

- for shares from GB - FTA All share Index,

- for international shares - FT/Standard \& Poor World (not including UK) Index,

- for North American shares - FT/Standard \& Poor North America Index,

- for European shares - FT/Standard \& Poor Europe (not including UK) Index,

- for Japanese shares - FT/Standard \& Poor Japan Index,

- for Asian-Pacific shares - FT/Standard \& Poor World Asia-Pacific (not including Japan) Index,

- for GB shares - British Government Stocks Index,

- for international shares - JP Morgan Global (not including UK) Bonds Index,

- for GB index-linked shares - British Government Stocks Index-linked Index,

- for money - LIBID (London Inter-Bank Bid Rate) 7-day deposit rate,

- for GB assets - Evaluation Association All Property Index,

- overall portfolio - WM Pension Fund Index.

That is why in some publications for funds we often cannot find nominal or real yields achieved in a period, but their result in relation to a benchmark.

Furthermore, different countries calculate the results of their funds through different methods. For example, in the Netherlands since 1998, measurement was initiated through Z-score test for all pension funds members of the association "Dutch Association of Industry-wide Pension Funds". This kind of measurement is interpreted by the belief that the achieved yield is not the only measure of success, since it has to be put in relation with investment risk that depends on the characteristics of the fund. ${ }^{31}$

A fund with older members, which will have significant payments of funds in the near future, will have less invested funds in shares as opposed to a fund with younger

${ }^{29}$ G. Timothy Haigh, S. Morrell “The Analysis of Portfolio Management Performance”, McGraw-Hill, 1997.

${ }^{30}$ D. Blake, A. Timmermann: "Performance Benchmarks for Institutional Investors: Measuring, Monitoring and Modifying Investment Behaviour" The Pension Institute, Birkbeck College, University of London, June 2002.

31 Press Briefing: "Industry-wide pension funds all passed performance test" April 2, 2004. 
members. Measurement of efficiency and effectiveness of a fund's activity must take into consideration such realistic differences.

However, when some systems do state the same categories of achieved yield, even then there are problems of comparison and data interpretation, because the defined formulas and ways of calculation differ from country to country. Even the basic definitions that explain different kinds of funds have different meanings in different countries. This is the reason for starting the initiative of aligning terminology and definitions, so that everybody is clear on what is discussed when using terms such as - DB, DC, Mandatory, Voluntary, Occupational, and so on.

By noticing the problem of insufficient possibility of comparing fund performance, the OECD reacted in 2002 by initiating the "Global Pension Statistic Project" with the purpose of creating a pension funds data base. A standard was initiated that will, in the future, give comparable data about the performance of pension funds. ${ }^{32}$

Croatian pension funds also fit into the data of pension funds' investments in other developed countries. Legal regulations in Croatia prescribe the structure of investments of pension funds. The quantity and the kind of domestic and international securities in which the pension funds can invest are prescribed. On the international capital markets, one can only invest only in the securities of an issuer whose headquarters are in a country that is part of the European Union, or member of OECD.

Figure 1: Structure of pension funds' investments in Croatia

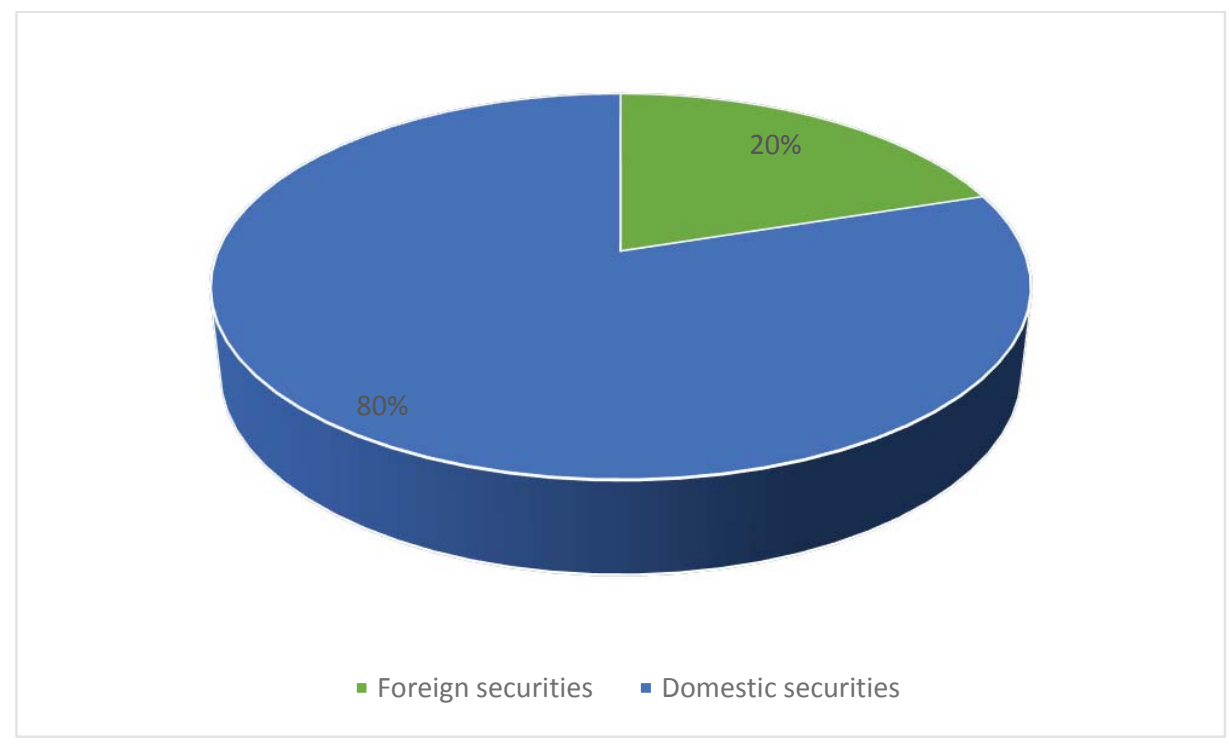

Source: http://www.rmf.hr/default.aspx?id=44, (25.10.2012.)

32 OECD, Directorate for Financial and Enterprise Affairs “Global Pension Statistics: Assesment of Valuation Methods". 
By the day of Croatian accession to the European Union, the limit for investment into foreign assets was the amount of $20 \%$ at the most. However, after Croatia entered the EU, the limitations were abolished. The assets of a pension fund can be, according to regulations in force, invested in:

- domestic and foreign government securities and securities whose issuer is the Croatian National Bank or a foreign central bank, or in debt securities guaranteed by the listed givers, with no limitations,

- domestic and foreign municipal and corporate bonds and other debt securities, up to the level of $30 \%$ of assets,

- domestic and foreign shares, up to the level of $30 \%$ of assets,

- shares of domestic and foreign open investments funds, i.e. the shares of closed investments funds, up to the level of $30 \%$ of assets,

- deposits, conformation of stakes, or repo businesses at a domestic or a foreign bank, up to the level of $20 \%$ of assets,

- other forms of assets, determined by Croatian Financial Services Supervisory Agency.

By the day of Croatian accession to the EU, the assets of pension funds had to be invested in securities whose issuer is Croatia, i.e. the Croatian National Bank, at least up to the level of $50 \%$ of the assets of the pension fund. When investing, spot contracts could have been used, while options and other financial instruments could have been used only for protecting the assets of the pension fund. Croatian Financial Services Supervisory Agency prescribes additional limitations and guidelines on how to invest in some forms of assets.

In the three comparable years of funds' work (2002, 2003, and 2004), their average real annual yield was 5.46\%, a bit higher than the Dutch and a bit lower than those of other developed countries. ${ }^{33}$

This was the result of the price growth on the global markets of debt (the decline of yields to an all-time minimum) which was going on at the time, while the Croatian pension funds had between $70 \%$ and $90 \%$ (and even more) assets invested in Croatian bonds. Still, the question remains what yields will be made in the next long-term period when the recovery of the share indexes is expected, if the domination of compulsion of investing in state bonds continues.

\footnotetext{
33 Štimac, D., Sopta, M.: Regulatory Framework for Pension Funds, Returns and Risk, 3rd International Conference - An Enterprise Odyssey: Integration or Disintegration, Faculty of Economics and Business, Zagreb, 2006.
} 


\section{DECISION THEORY AND CORPORATE SOCIAL RESPONSIBILITY}

By studying corporate social responsibility, we seek to find an adequate way of applying these activities, and the best way is through the decision theory. Management must foresee the advantages of implementation of corporate social responsibility, so it can make the final decision. Another important component in the process of decision making is when and how to apply corporate social responsibility.

For previously asked questions, it is necessary before anything else, to view the market as a whole, as well as the legislation in force and current conditions. The circumstances in which the decision theory should be applied depends largely on the decision-maker. By analyzing possible repercussions of applying corporate social responsibility, the manager must make a decision that will have positive effects for the management board, the owners, the employees and the state. It is hard to satisfy the needs of all involved in the process, but in a way, corporate social responsibility overpowers their individual interests and unites them in a common basket of goals.

Therefore, decision theory is a mechanism through which it is possible to implement the principles of corporate social responsibility. The criteria of choices of actions in some areas of corporate social responsibility is a framework determined by the set goals of decision making, which enables a successful comparison of available actions that should result in choosing the option that is better at fulfilling the set goals than the others.

\section{EMPIRICAL RESEARCH OF SOCIALLY RESPONSIBLE INVESTMENTS}

\subsection{Methodological aspects of the research}

With the purpose of fulfilling the research goals, the methodological approach of testing the hypothesis and achieving the expected scientific contribution is based primarily on research, as well as collecting and processing relevant secondary data.

Secondary data was used during the process of completing the theoretical part of the research, and the method of analysis and synthesis was applied to information gathered from domestic and foreign literature. Additional methods were used for the purpose of the research: comparative analysis, induction and deduction, classification, compilation, description, abstraction and concretization, generalization and specialization, proving and refuting, statistical and historical methods, method of survey.

Statistical, analytical and comparative methods were used for proving the stated. In addition, a comparative analysis of all mandatory pension funds in Croatia was carried out in the practical part that will be presented and which was carried out by using the method of inquiry of their board presidents, since they are best informed about the decision making criteria for investment. A survey questionnaire was used during the inquiry and the sample includes all mandatory pension funds in Croatia. The board 
presidents and the board members of the four mandatory pension funds revealed that there is a link between making investment decisions and corporate social responsibility of joint stock companies that have already been or will become a potential subject of funds' investments.

\subsection{Review and interpretation of results}

\subsubsection{PBZ-CO pension companies}

The main mission of the mandatory pension fund PBZ Croatia osiguranje is to ensure the fund members maximum security for their paid-up funds, to prevent the loss of value of their paid-up funds due to inflation or an appreciation of the domestic currency, and to ensure a competitive yield on invested resources. By its nature the fund is conservative. When investing, the main goal is to take care of the safety of the fund's assets, and then to consider the profitability of investment. The company will trade in private assets of the fund with due diligence, exclusively in the interest of fund members and according to the funds' investments goals, which are:

- to ensure maximum safety for paid-up funds of fund members,

- to prevent the loss of value of paid-up funds due to inflation or an appreciation of the domestic currency,

- to insure the yield on paid-up funds according to market conditions.

The investment goals of the fund are set according to these principles:

- safety of investment,

- diversity of investment,

- maintenance of suitable liquidity.

Safety, diversity and liquidity of investments and achieving yields will be accomplished by abiding to legally prescribed instruments of investment, respecting the limitations of investments, as well as by carefully and comprehensively analyzing the risk of the instruments and their issuers in which the assets of the fund will be invested. The auditing commission of the company has insight into business results of both the company and the fund.

The structure of the portfolio is in accordance with the accepted principles and investment goals. Safety is guaranteed by investing in state bonds of Croatia, and the liquidity and diversity are in accordance with the limitations of investment of the Fund's assets. The structure of investing the assets of the fund by type of assets as on 31 December 2010 is shown in the following table. It indicates that the largest investment this fund has had is in domicile bonds of Croatia and CNG (61.91\%) as it offers the safest yield. However, $18.88 \%$ is invested in domicile shares. 
Table 2: The structure of investment by type of asset as on 31 December 2010

\begin{tabular}{|c|c|c|}
\hline Position & Value (HRK) & Shares in total fund assets \\
\hline Net value of fund assets & & $6.144 .940 .129,31$ \\
\hline Total value of fund as sets & $6.160 .293 .629,32$ & $100,00 \%$ \\
\hline Cash & $8.801 .097,54$ & $0,14 \%$ \\
\hline HRK & $6.415 .769,00$ & $0,10 \%$ \\
\hline other currency & $2.385 .328,54$ & $0,04 \%$ \\
\hline Claims & $63.819 .502,20$ & $1,04 \%$ \\
\hline Deposits & $74.031 .177,04$ & $1,20 \%$ \\
\hline $\begin{array}{l}\text { Shortterm securities MFIN } \\
\text { \& HNB }\end{array}$ & 0 & $0,00 \%$ \\
\hline Domestic bonds RH \& HNB & $3.814 .125 .060,05$ & $61,91 \%$ \\
\hline Domestic municipal bonds & $29.824 .503,38$ & $0,48 \%$ \\
\hline Domestic corporate bonds & $243.357 .086,57$ & $3,95 \%$ \\
\hline $\begin{array}{l}\text { Domestic shares, shares of } \\
\text { ZIF i GDR }\end{array}$ & $1.162 .947 .474,90$ & $18,88 \%$ \\
\hline $\begin{array}{l}\text { Domestic shares, shares of } \\
\text { ZIF i GDR }\end{array}$ & $1.102 .923 .368,92$ & $17,90 \%$ \\
\hline Domestic shares of ZIF & $17.400 .000,00$ & $0,28 \%$ \\
\hline GDR & $42.624 .105,98$ & $0,69 \%$ \\
\hline Foreign government bonds & 0 & $0,00 \%$ \\
\hline Foreign bons & $150.366 .435,11$ & $2,44 \%$ \\
\hline Shares in OIF & $550.518 .037,49$ & $8,94 \%$ \\
\hline Domestic OIF & $88.827 .135,71$ & $1,44 \%$ \\
\hline Foreign OIF & $461.690 .901,78$ & $7,49 \%$ \\
\hline Domestic commercial paper & $62.503 .255,04$ & $1,01 \%$ \\
\hline Structured securities & 0 & $0,00 \%$ \\
\hline \multicolumn{2}{|l|}{ Liabilities } & $-15.353 .500,01$ \\
\hline
\end{tabular}

Source: Bulletin PBZ-CO Municipal Pension Fund, http://www.pbzco-fond.hr/aboutus/reports2. aspx, (29.10.2012.) 
Table 3: List of all investments that make $1 \%$ or more of the total assets of the pension fund as on 31 December 2010

\begin{tabular}{|c|c|c|c|c|c|c|}
\hline Issued by & Security type & ISIN & Quantity & Currency & $\begin{array}{l}\text { Unit price } \\
\text { (local currency) }\end{array}$ & Total value (HRK) \\
\hline \multicolumn{7}{|l|}{ Deposits } \\
\hline Deposit - Hypo & & & 65.007 .955 & HRK & & $65.007 .954,6$ \\
\hline \multicolumn{7}{|c|}{ Regular shares Ltd.'s from Republic of Croatia } \\
\hline INA Ltd. & $\begin{array}{l}\text { INA REGULAR } \\
\text { SHARES }\end{array}$ & HRINAORA0007 & 59.330 & HRK & $3.174,73$ & $188.356 .475,7$ \\
\hline Adris Grupa Ltd. & $\begin{array}{l}\text { Adris REGULAR } \\
\text { SHARES }\end{array}$ & HRADRSRA0007 & 256.214 & HRK & 317,14 & $81.254 .657,4$ \\
\hline Zagrebačka banka Ltd. & $\begin{array}{l}\text { HT REGULAR } \\
\text { SHARES }\end{array}$ & HRZABARA0009 & 299.198 & HRK & 251,88 & $75.362 .620,5$ \\
\hline Podravka Ltd. & $\begin{array}{l}\text { Podravka } \\
\text { REGULAR SHARES }\end{array}$ & HRPODRRA0004 & 349.974 & HRK & 305,05 & 106.759.708,6 \\
\hline Hrvatski telekom Ltd. & \begin{tabular}{|l} 
HT REGULAR \\
SHARES
\end{tabular} & HRHTOORA0005 & 1.188 .298 & HRK & 289,38 & $343.875 .022,5$ \\
\hline \multicolumn{7}{|c|}{ Regular shares of foreign Lts.'s } \\
\hline Krka Ltd. & $\begin{array}{l}\text { Krka REGULAR } \\
\text { SHARES }\end{array}$ & SI0031102120 & 248.029 & EUR & 63,00 & $115.399 .435,6$ \\
\hline \multicolumn{7}{|c|}{ Longterm bonds of Republic of Croatia } \\
\hline $\begin{array}{l}\text { Republic of Croatia - } \\
\text { Ministry of Finance }\end{array}$ & RHMF-O-19BA & HRRHMFO19BA2 & 16.350 .000 & EUR & $105,17 \%$ & $127.560 .759,7$ \\
\hline $\begin{array}{l}\text { Republic of Croatia - } \\
\text { Ministry of Finance }\end{array}$ & RHMF-O-142A & RHMFO142A8 & 17.909 .650 & EUR & $104,25 \%$ & $140.712 .135,4$ \\
\hline $\begin{array}{l}\text { Republic of Croatia - } \\
\text { Ministry of Finance }\end{array}$ & RHMF-O-203E & RHMFO203E0 & 157.050 .000 & EUR & $103,56 \%$ & $1.225 .464 .222,4$ \\
\hline $\begin{array}{l}\text { Republic of Croatia - } \\
\text { Ministry of Finance }\end{array}$ & RHMF-O-203A & RHMFO203A8 & 207.500 .000 & HRK & $101,70 \%$ & $215.554 .381,9$ \\
\hline $\begin{array}{l}\text { Republic of Croatia - } \\
\text { Ministry of Finance }\end{array}$ & RHMF-O-15CA & RHMFO15CA8 & 295.027 .238 & HRK & $102,02 \%$ & $301.668 .489,1$ \\
\hline $\begin{array}{l}\text { Republic of Croatia - } \\
\text { Ministry of Finance } \\
\end{array}$ & RHMF-O-17BA & RHMFO17BA6 & 405.000 .000 & HRK & $98,79 \%$ & 402.607.450,1 \\
\hline $\begin{array}{l}\text { Republic of Croatia - } \\
\text { Ministry of Finance }\end{array}$ & RHMF-O-172A & RHMFO172A5 & 660.300 .000 & HRK & $93,16 \%$ & $627.521 .706,5$ \\
\hline $\begin{array}{l}\text { Republic of Croatia - } \\
\text { Ministry of Finance }\end{array}$ & RHMF-O-137A & RHMF0137A8 & 722.200 .000 & HRK & $97,12 \%$ & $716.646 .820,3$ \\
\hline \multicolumn{7}{|c|}{ Shares in foreign OIF \& ETF } \\
\hline SPDR TRUST & SPDR S\&P 500 ETF & US78462F1030 & 190.600 & USD & 125,69 & $133.399 .833,8$ \\
\hline
\end{tabular}

Source: Bulletin PBZ-CO Mandatory Pension Fund, http://www.pbzco-fond.hr/aboutus/reports2.aspx, (29.10.2012.)

\subsubsection{Allianz ZB pension fund}

Allianz ZB d.o.o., a company managing a mandatory pension fund, was founded in September 2001 and, according to the Act on mandatory and voluntary pension funds, runs one mandatory pension fund in which contributions for mandatory pension insurance for the II. pension pillar are collected - the AZ mandatory pension fund. AZ is one of the largest mandatory pension funds in Croatia based on the number of its 
members. At the end of April 2010, there were 551272 registered members, or $35.98 \%$ of all members of all mandatory pension funds.

Other than in terms of the number of members, $\mathrm{AZ}$ fund is a leader in the value of assets it manages. At the end of April 2010, net assets of the fund were $12514270 \mathrm{HRK}$ or $39.39 \%$ of all assets under the management of all mandatory pension funds. For its members, the investment team has materialized an annual yield of 5.10\% (April 2002 April 2010). Allianz ZB Ltd. is a company founded in May 2002, and today it manages two open and three closed voluntary pension funds.

At the end of April 2010, AZ open voluntary pension fund had 73947 members, while the AZ funds with $48.71 \%$ of the market share had a leading position on the market of voluntary pension funds. The yields of the AZ open voluntary pension funds for AZ Profit from September 2003 until April 2010 amounted to 9.38\%, and from December 2003 until April 2010, the yield for AZ Benefit was 7.37\%. ${ }^{34}$

\subsubsection{Raiffeisen pension fund}

Raiffeisen pension fund is the sole proprietorship of Raiffeisenbank Austria d.d. Zagreb. The investment goals of the fund are long-term safety, adequate yield, protection of its members from the loss of value of paid-up funds due to inflation or appreciation of the domestic currency, with optimal growth of pension savings in relation to the risk taken. Raiffeisen mandatory mutual fund is by its nature conservative. When investing, safety, liquidity, diversity and profitability of investment are considered, and the limitations prescribed by the laws and regulations are abided by. The company manages the private fund assets with due diligence, regardless of the bank administrator and exclusively in the interest of the owners of shares in the fund. Assets of the fund are kept separate from the assets of the pension company.

Table 4: The structure of investments by type of assets as on 31 December 2011

\begin{tabular}{|l|r|r|}
\hline \multicolumn{1}{|c|}{ Position } & Amount (HRK) & $\begin{array}{c}\text { Shares in total } \\
\text { fund assets }\end{array}$ \\
\hline Securities whose issuer is Republic of Croatia, a member of the EU or OECD and CNB and CB's of EU and OECD members & $8.628 .238 .077,62$ & $69,82 \%$ \\
\hline Bonds for which the Republic of Croatia, an EU or OECD member and CNB and CB's of EU and OECD members guarantee & $37.093 .990,91$ & $0,30 \%$ \\
\hline Corporate bonds and other corporate securities that were issued by an issuer from Croatia or a member of the EU or OECD & 0,00 & $0,00 \%$ \\
\hline Municipal bonds and other municipal securities that were issued by an issuer from Croatia or a member of the EU or OECD & $650.103 .289,34$ & $5,26 \%$ \\
\hline Shares of firms with residence in Croatia, or a member of the EU or OECD that trade their stocks on organised markets & $2.126 .233 .601,59$ & $17,20 \%$ \\
\hline Shares of open investment funds registered in Croatia, or a member of the EU or OECD & $758.723 .743,16$ & $6,14 \%$ \\
\hline Shares of closed investment funds registered in Croatia, or a member of the EU or OECD & $6.312 .865,79$ & $0,05 \%$ \\
\hline Deposits, certificated of stakes or repo businesses with the bank that has residence in Croatia, or a member of EU or OECD & $9.972 .099,63$ & $0,08 \%$ \\
\hline Funds in the business account & $6.625 .269,79$ & $0,05 \%$ \\
\hline Liabilities & $135.345 .304,58$ & $1,10 \%$ \\
\hline Total assets & $12.358 .648 .242,41$ & $100,00 \%$ \\
\hline
\end{tabular}

Source: http://www.rmf.hr/24.10.2012

${ }^{34}$ http://www.azfond.hr/o-nama/az-fondovi, 24.10.2012. 
During 2011, the investment of the fund was conservative. On average, $66.19 \%$ of the assets was invested in domicile state bonds and treasury bills and 5.52\% in domicile corporate bonds and commercial bills. The share of investment in shares of domicile joint stock companies and closed investment funds amounted to an average of $18.66 \%$, while investment in shares of domicile open investment funds was on average $1.92 \%$ of the fund's assets. On average, $8.34 \%$ of the fund's assets was invested in foreign securities.

Table 5: Investments that made $1 \%$ or more of the total assets of the fund as on 31 December 2011

\begin{tabular}{|c|c|c|c|c|c|}
\hline Position & Issuer & Quantity & Unit price (HRK & $\begin{array}{c}\text { Value on the date of } \\
\text { the report }\end{array}$ & $\begin{array}{l}\text { Shares in } \\
\text { total fund } \\
\text { assets }\end{array}$ \\
\hline RHMF-0-15CA & Republic of Croatia & 2.841.500.000 & 1,0387 & 2.952.386.065,97 & $23,89 \%$ \\
\hline RHMF-0-203A & Republic of Croatia & 1.430 .730 .000 & 1,0503 & $1.502 .678 .716,81$ & $12,16 \%$ \\
\hline RHMF-0-227E & Republic of Croatia & 195.051 .800 & 7,3963 & $1.442 .659 .094,15$ & $11,67 \%$ \\
\hline RHMF-0-203E & Republic of Croatia & 150.220 .500 & 7,6189 & 1.144.511.216,57 & $9,26 \%$ \\
\hline HT-R-A & HT Ltd. & 4.384 .469 & 241,5620 & 1.059.121.100,58 & $8,57 \%$ \\
\hline RHMF-0-142A & Republic of Croatia & 110.000 .000 & 7,6302 & $839.322 .310,49$ & $6,79 \%$ \\
\hline RHMF-0-17BA & Republic of Croatia & 499.000 .000 & 0,9664 & $482.249 .228,02$ & $3,90 \%$ \\
\hline AGROKOR 2016 & Agrokor Ltd. & 48.360 .000 & 7,5384 & $364.555 .580,01$ & $2,95 \%$ \\
\hline iShares DAX (DE) & $\begin{array}{l}\text { BlackRock Asset Management } \\
\text { Deutschland AG }\end{array}$ & 869.100 & 406,5674 & $353.347 .706,31$ & $2,86 \%$ \\
\hline INA-R-A & INA Ltd. & 80.000 & $3.800,0000$ & $304.000 .000,00$ & $2,46 \%$ \\
\hline ATGR-R-A & Atlantic Grupa Ltd. & 313.084 & 500,0058 & $156.543 .815,89$ & $1,27 \%$ \\
\hline ERNT-R-A & Ericsson Nikola Tesla Ltd. & 121.486 & $1.080,0000$ & $131.204 .880,00$ & $1,06 \%$ \\
\hline
\end{tabular}

Source: http://www.rmf.hr/24.10.2012.

From the previously presented tables, the safety of investments is visible, for the RBA mandatory pension fund, as well for all previously described funds. Also, the largest share of $67 \%$ of total investments are domicile government bonds.

\subsubsection{Erste Plavi pension fund}

Erste Plavi pension fund is in 37.94\% ownership of Erste\&Steiermarkische Bank d.d., while $29 \%$ of the shares are owned by TBIH Financial Services Group NV, and $12.5 \%$ is owned by Erste Gorup Bank AG and Steiermarkische Bank und Sparkasse AG. $6.17 \%$ is owned by Slovenian Zavorovalnica Triglav and $2.47 \%$ by Istarska kreditna banka d.d. Umag.

The number of members as on 30 April 2010 was $235896 .{ }^{35}$ More than seven years of doing business of mandatory pension funds was assessed successful, with an

\footnotetext{
${ }^{35}$ http://www.ersteplavi.hr/default.aspx?ID=21, 25.10.2012.
} 
average yearly yield of 5.65\% achieved between April 2002 and April 2010. By uniting financial strength, experience and the fact that the funds of Erste Plavi fund are run by experienced fund managers, by investing in first class securities, they bring necessary safety to their members.

Figure 2: Ownership structure of Erste mandatory pension fund

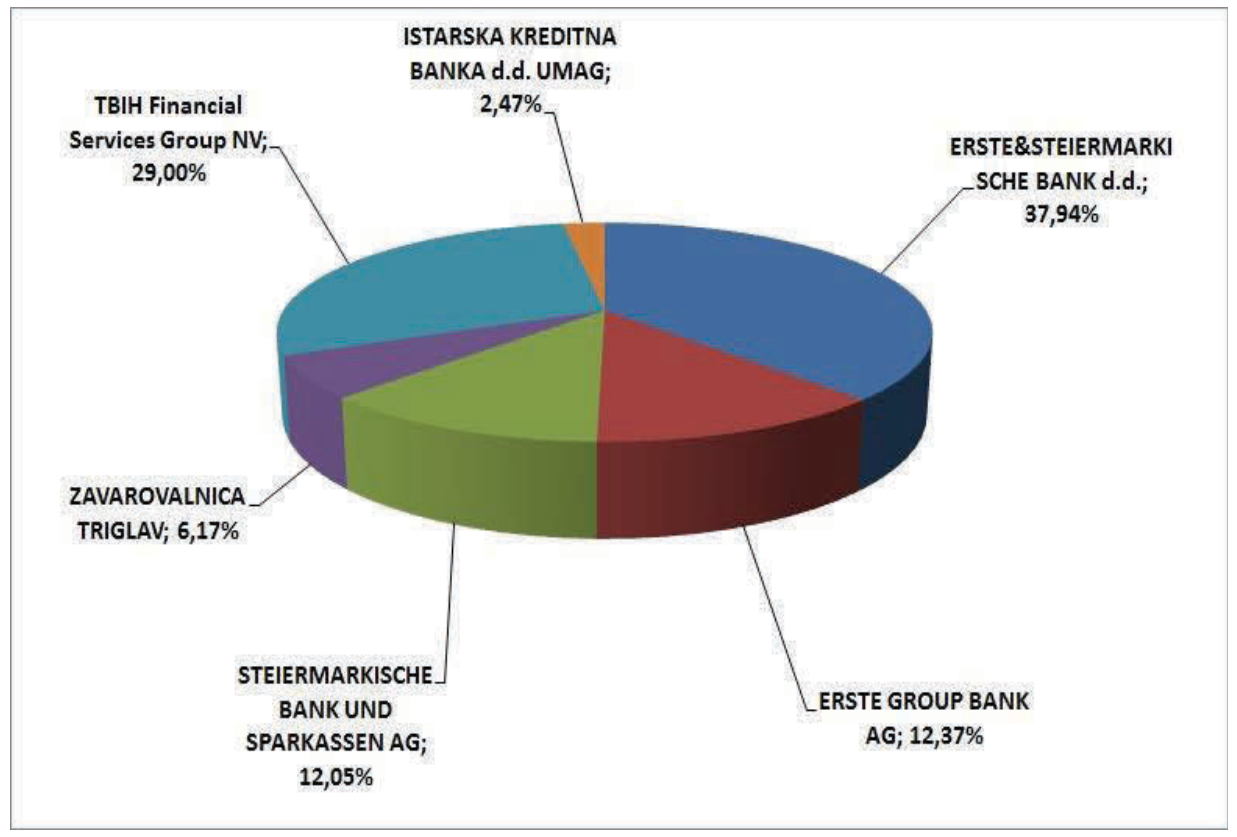

Source: http://www.ersteplavi.hr/default.aspx?ID=21 (25.10.2012.)

\section{RESEARCH}

Now that the informative display of all mandatory pension funds in Croatia has been made, the paper presents the results of the research that was conducted in all the above stated funds, and refers to corporate social responsibility. It is necessary to point out that the answer to the call for surveys was $100 \%$. Until this research, corporate social responsibility was not put into connection with pension funds in Croatia. After their growing engagement on the market as shareholders of companies important for the economy, the question arises of how crucial or important the criteria of corporate social responsibility is for pension funds while investing? According to this, the first hypothesis of the research is set:

H1: Shareholders' activities can make companies respond to changed external circumstances, which contributes to long-term profitability and sustainability. 
Figure3: Is it noticeable that joint stock companies in which mandatory pension funds in Croatia plan to invest are starting to apply corporate social responsibility as a positive determinant for investments?

\section{Acceptance of CSR by firms in which Mandatory Pension Funds should invest}

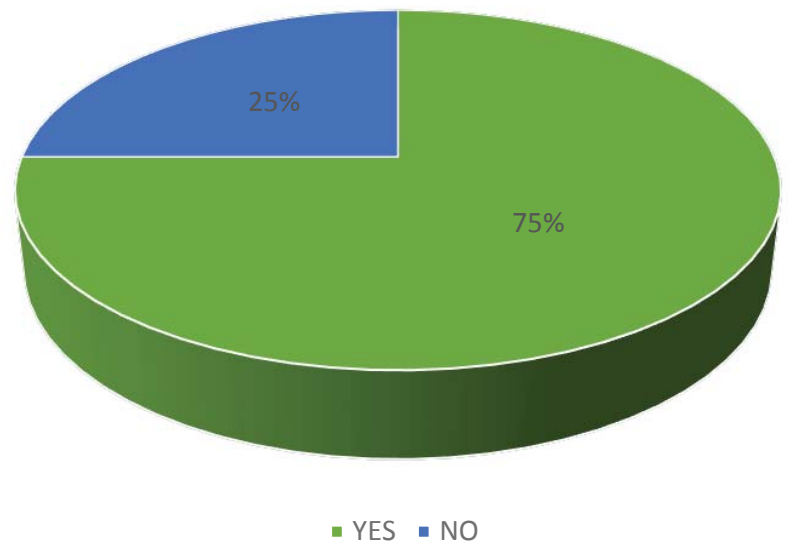

Source: Author's research made for the purpose of making a Master's thesis

The chart above shows the results of a research in which the first hypothesis of the research is confirmed. Out of the total of surveyed respondents or board presidents, $75 \%$ of them answered that they noticed that during showing interest on the market to invest in a company, the activities in the sphere of corporate social responsibility are quickly recognized, and in their opinion, the market perception of that company's image changes. The companies or joint stock companies that wish to attract attention of potential investors on the market, in this case, mandatory pension funds, try to undertake the activities that best present the image of their company.

Apart from financial indicators, corporate social responsibility imposed itself as a new form of activity which can single out the company from its competition. The following hypothesis is also completely proved: corporate social responsibility ensured long-term profitability and sustainability, and the results of the research are presented in the next chart. 
Figure 4: Corporate social responsibility ensures long-term profitability and sustainability

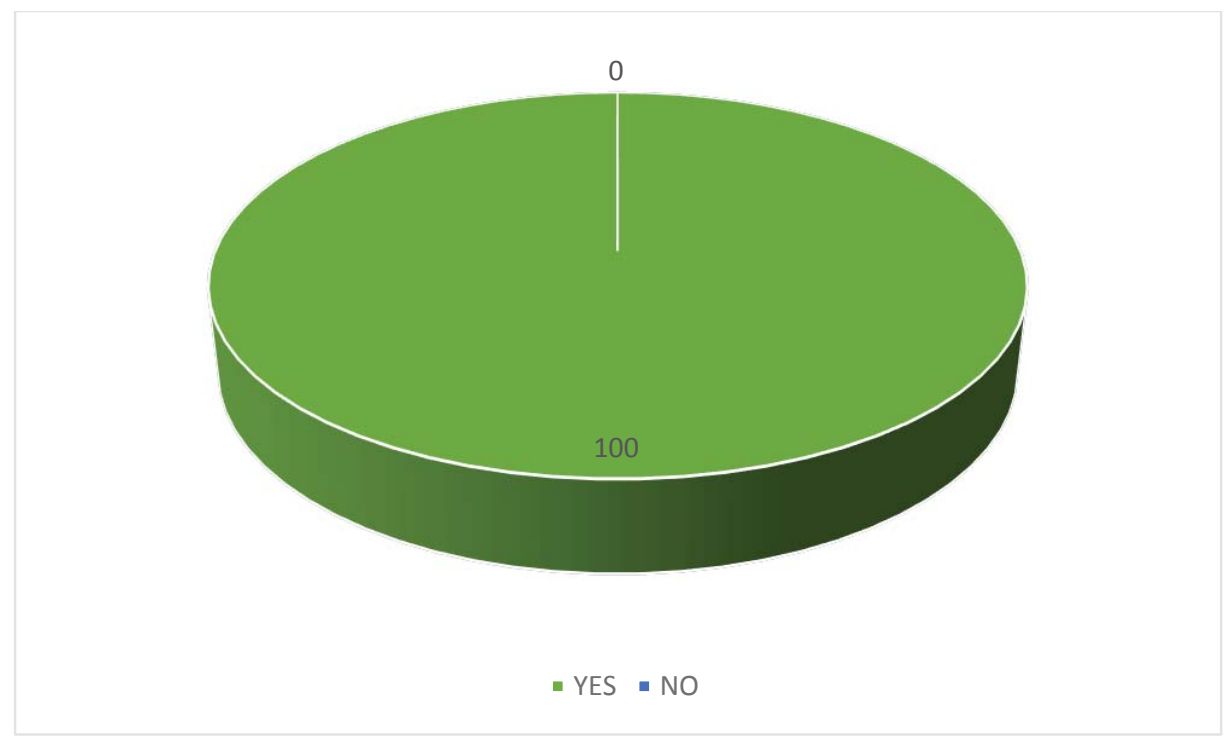

Source: Author's research made for the purpose of making a Master's thesis

H2: Pension funds in Croatia have an increasing role in the management structures of a growing number of joint stock companies, which strengthens their role as market actors in the whole economic system

Unfortunately, the analysis that would confirm the second hypothesis could not be carried out, nor has such an analysis been conducted by pension funds or by state institutions. In the last three years, other than in safe government bonds, mandatory pension funds invest more and more in shares of other companies. This phenomenon began being visible with the start of the financial crisis. The numbers that support this statement can be found in the statements shown previously in this paper, for all pension funds separately. Some funds did not have such data, at least not publicly published.

As the result of the financial crisis in Croatia, and it appears that the trend on other markets are the same, there has been a reduction of strength on the market of those institutional investors that were, up until that point, the carriers of corporative movement. Even though this has not been the base activity of mandatory pension funds, they have, because of the current financial situation, started to involve themselves into the management structures of joint stock companies in which they invested, and have taken up some roles they have not had up until then. That only indicates that, according to the structure of capital, pension funds were managed well, and therefore their role as market players is growing in the overall economy. 
H3: Mandatory pension funds in Croatia take into consideration corporate social responsibility as key criteria when investing.

Figure 5: When mandatory pension funds in Croatia invest in other joint stock companies, is corporate social responsibility taken into consideration?

\section{Is corporate social responsibility considered as a criterion during the assessment of investment opportunities of mandatory pension funds in Croatia}

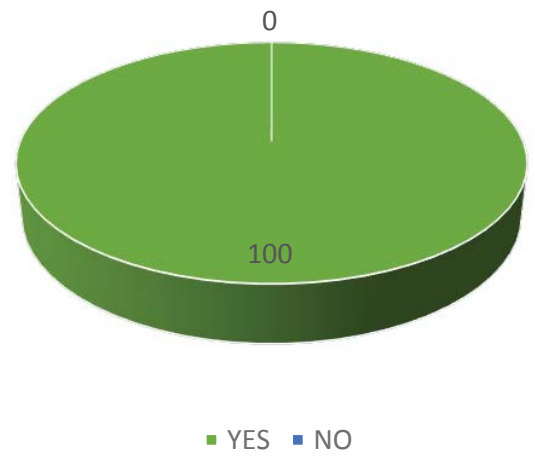

Source: Author's research made for the purpose of making a master's thesis

This hypothesis is partly proven. It has been proven that corporate social responsibility is important to pension funds while observing the criteria (100\% of the surveyed respondents confirmed this statement). In this thesis we can find the answer to the question of how important it is to them. $25 \%$ answered it is extremely important, while $50 \%$ considered it to be important, but not extremely so.

Further evidence of rejecting part of the hypothesis lies in the fact that $50 \%$ of the surveyed board presidents considered corporate social responsibility important, but not a crucial criterion for mandatory investment funds in Croatia making investment decisions.

Even tough half of the surveyed respondents answered that the criterion is crucial, in discussion with them the conclusion was reached that the Croatian capital market is not developed enough to consider exclusively corporate social responsibility. There is a lower number of joint stock companies on the market in which they could invest than in developed countries, where the standards have been set and where corporate social responsibility has a significantly higher importance. 
Figure 6: Importance of corporate social responsibility for mandatory pension funds in Croatia

Marked on a scale, how important is corporate social responsibility of firms in which Croatian mandatory pension funds plan to invest?

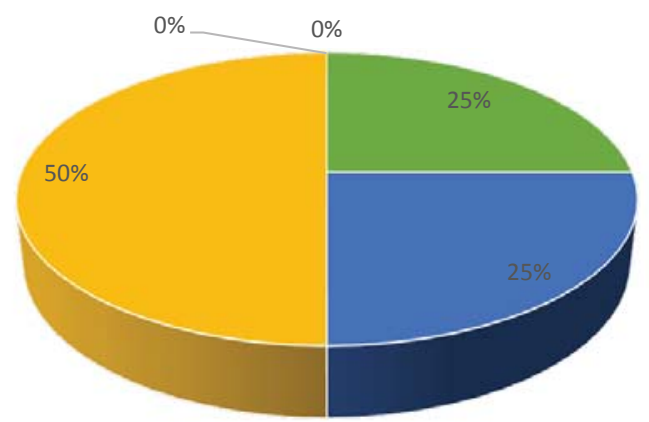

- 5 - Extremly important $4 \quad 4 \quad$ - 2 - 1 - Not taken into consideration

Source: Author's research made for the purpose of making a Master's thesis

Partial confirmation of the third hypothesis is shown in the next chart.

Figure 7: Implementation of corporate social responsibility as a crucial factor for investment decision making of mandatory investment funds in Croatia

Corporate social responsibility is a crucial factor when deciding wheather or not the mandatory pension fund will invest

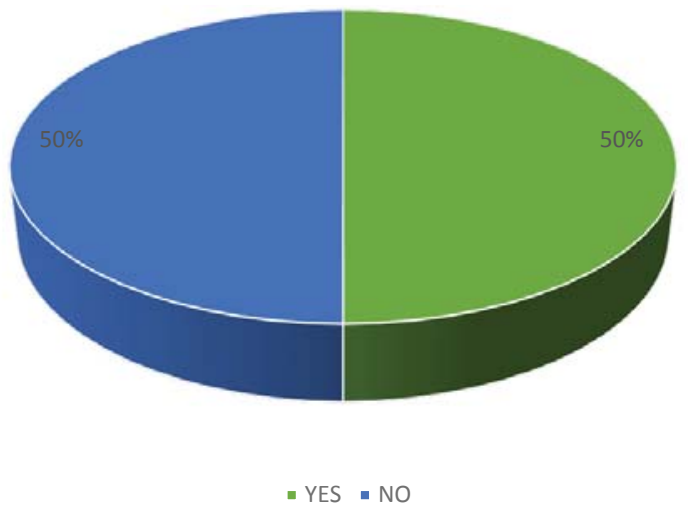

Source: Author's research made for the purpose of making a Master's thesis 
For the following question, multiple answers were offered, and therefore the results are shown adequately. Almost all areas of corporate social responsibility are interesting for mandatory pension funds when investing.

Chart 8: Areas activity of corporate social responsibility

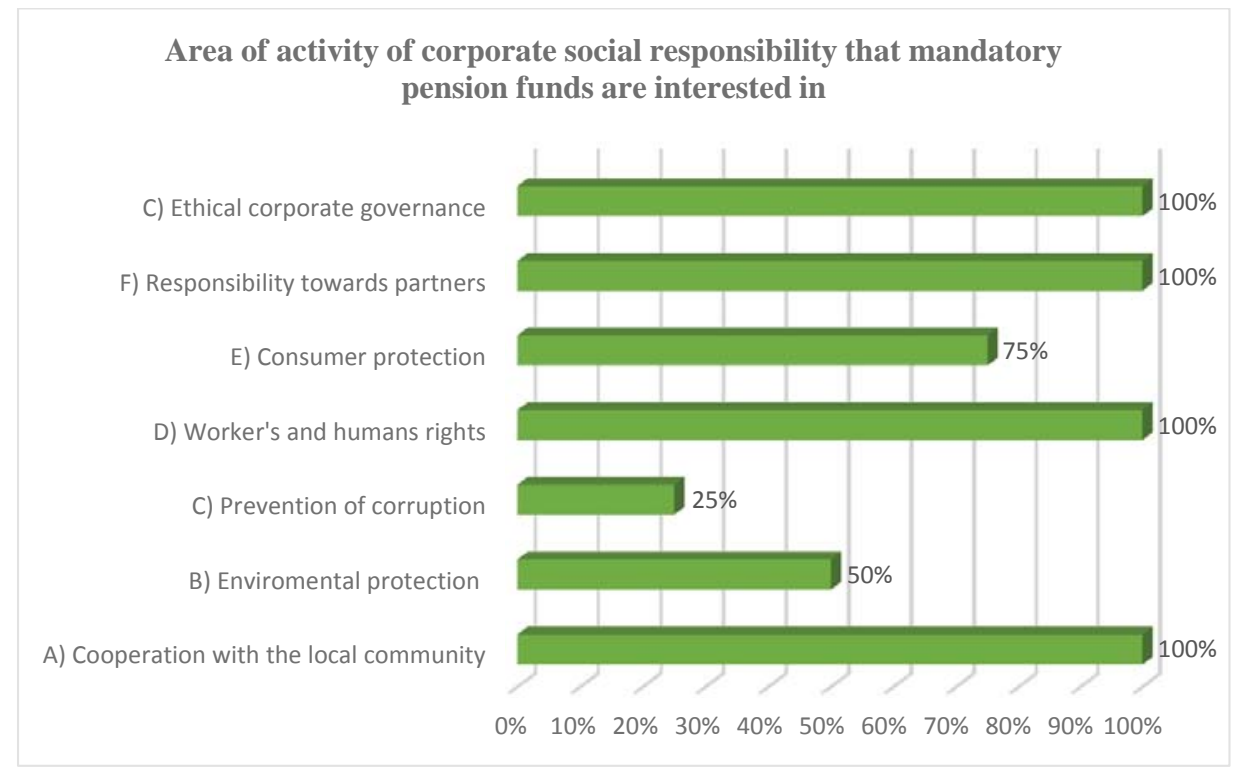

Source: Author's research made for the purpose of making a Master's thesis

\subsection{Limitations of the conducted research}

Limitations in conducting the research have already appeared during the collection of the secondary data for proving the degree of application of corporate social responsibility in other developed countries of the European Union, as well as the rest of the world. This is due to the fact that there is no unified way of valorizing the degree of application of corporate social responsibility, only the practical examples that can be used as occurrences.

It is also hard to correlate the effect of applying corporate social responsibility and the growth and development of the firm (joint stock companies), as well as the society as a whole. What could have been proved are the statements of board presidents of all mandatory pension funds in Croatia who filled the survey, and according to their professional judgement obtain confirmation of the influence of corporate social responsibility on specified values.

Furthermore, due to the relatively newly formed mandatory pension funds, the information for a more serious analysis of time series could not have been obtained. We can only assume that it would be interesting to observe. It is also important to point out 
that our capital market is not as strongly developed as in other developed countries, and therefore it is not to be expected that pension funds will take corporate social responsibility as a key criterion for investment analysis. For example, should they invest in Tvornica duhana Rovinj (Tobacco factory Rovinj) whose business, even though it has a good yield on the market and is a safe wager, may not coincide with the principles corporate social responsibility such as consumer health protection? Such and similar questions offer lots of unknown facts that appear during this paper.

\subsection{Implications for further research}

The analyzed research problem in the paper establishes the research task whose purpose could be described as shedding light on the disposition and structural background of the phenomenon of corporate social responsibility. Throughout this paper, the areas of corporate social responsibility can be discerned, as well as the importance of its systematical monitoring for management's purposes, as well as for the needs of the owners and investors themselves, in this case of mandatory pensions funds.

A statistical record of corporate social responsibility has not been kept in Croatia, neither by the government and its institutions, nor by joint stock companies. Therefore, the analysis was conducted by means of a survey. For providing the most relevant data, the survey was conducted among board presidents.

By focusing on the importance of identifying this issue and by offering examples from European and world practice, the direction of deeper analysis of corporate social responsibility is imposed. First, this can be done through financial categories, and then through measuring the satisfaction of management members, employees and consumers. New integration changes must not be forgotten, and with them the opening and adjusting to new markets whose awareness about corporate social responsibility is on a higher level.

It is important to link the development of corporate social responsibility with the effect on the economic crisis that affected not only Croatia but all global markets, and on a sociological level try to find the solution to various problems that plague a growing number of unemployed persons.

\section{CONCLUSION}

Authors hope that the above presentation of facts not only justifies the title of the thesis, but also proves an important role and significance of corporate social responsibility. In the introductory part of the research questions were elaborated and formulated in the form of hypotheses. Applied and scientific goals were set. The used methodology was detailed, as well as the expected contribution of the work. In the second chapter of the paper the theoretical approach was taken towards control economics as a necessary tool by which decisions are made about social responsibility. Next, compulsory Croatian pension companies were presented in order to demonstrate the key elements when mandatory pension funds in Croatia choose to invest. In the fourth part of the paper, corporate social responsibility was incorporated into decision theory. The sixth part of the thesis provided 
and overview of the empirical research that was divided into three parts. The first part was the explanation of the methodology of research, followed by a detailed description and interpretation of results. Finally, the limitations of the research were explained.

With the development of global economy, it becomes clearer that large joint stock companies have taken over the responsibility from government institutions to implement the principles. Large corporations must become active agents of social changes, if this makes the world safe for democracy and capitalism, because capitalism can only last in an environment of uninhibited personal choice where it can be voluntarily achieved in the political and economic arena. As dominant institutions in the society, corporations must take their rightful place and contribute to the articulation of the public agenda in the form of corporate social responsibility. In today's pluralistic society, joint participation in social political formulation is not a luxury but a necessity, and this issue needs to get the attention of the management.

As already noted, it is important to link the development of corporate social responsibility with the impact of the economic crisis that affected not only Croatia but all global markets, and on a sociological level try to find the solution to various problems that plague a growing number of unemployed persons.

The research problem that has been analyzed in the thesis justifies the research task whose purpose is shedding light on the disposition and structural background of the phenomenon of corporative social responsibility. The paper provides a discernment of the areas of corporate social responsibility and presents the importance of its systematic monitoring, for the needs of both the management and the owner, as well as those of the investors - the mandatory pension funds.

Mandatory pension funds and other large institutional holders can play a key role in improving the overall quality of corporate governance. The goal would be that all corporations meet the minimum standard of reference regarding the impact of their activities on the society. After all, work cannot thrive in a hostile socio-political environment. Business cannot grow where the cumulative effects of negative externalities are increasing to such an extent that it adds significantly to the cost of meeting regulatory requirements.

By analyzing the results of research and by talking to the respondents, it was concluded that corporate social responsibility is important, but not an essential criterion when mandatory pension funds in Croatia make investment decision. In developed countries, there are a number of cases where this is the most important issue when investing. This is caused by the fact that the Croatian capital market is not yet developed enough to exclusively take into consideration corporate social responsibility when making investment decisions. The number of joint stock companies on the Croatian market in which one could invest is much lower than in developed countries where there are standards in place and where social responsibility is certainly of greater importance.

There is no doubt that corporate social responsibility will gain more importance, especially when taking into account the Croatian accession to the EU. The capital market will be more available, and thus the supply and demand more diverse. It is also difficult to correlate the effects of applying corporate social responsibility to the growth 
and development of companies and joint stock companies as well as to the society as a whole. What could have been proved were the statements from the board presidents of all mandatory pension funds in Croatia who filled out the questionnaire. According to their professional judgment, confirmation was obtained of the influence of corporate social responsibility to the specified value.

\section{REFERENCES:}

1. Berk, J., Demarzo, P: Corporate Finance, Pearson International edition Boston, 2007.

2. Bird, R. et al.: What Corporate Social Responsibility Activites are Valued by the Market?, Journal of Business Ethics, 76 (2), 2007.

3. Blake, D., A. Timmermann, A.: "Performance Benchmarks for Institutional Investors: Measuring, Monitoring and Modifying Investment Behaviour" The Pension Institute, Birkbeck College, University of London, June 2002.

4. Brealey R.A., Myers S.C., Marcus, A.J.: Osnove korporativnih financija, Mate d.o.o., Zagreb, 2007.

5. Clarke, T.: Theories of Corporate Governance: The Philosophical foundations of Corporate Governanace, London: Routledge, 2004.

6. Colley, J.L.Jr., Doyle, J.L.. Logan, G.W. i Stettinius, W.: Corporate Governance, McGraw-Hill, New York, 2003.

7. Commission of te European Communities: Communication from the concerning corporate social responsibility; A business contribution to sustainable development, COM, 347, 2008.

8. Friedman, M.: “The Methodolgy of Positive Economics” u M. Friedman, Essays on PositiveEconomics, Chicago: University of Chicago Press, 1953.

9. Friedman, M.: "Kapitalizam i sloboda”, Globus, Zagreb, 1992.

10. Galetić, L. i suradnici: Organizacija velikih poduzeća, Sinergija, Zagreb, 2011.

11. Grant, G. H.: The Evolution of Corporate governance and its Impact on Modern Corporate America, Managment Decision, 41 (9), 2003.

12. Haigh, T., G., Morrell, S.: “The Analisis of Portfolio Management Performance”, McGraw-Hill, 1997.

13. Jensen, M.C.: Eclipse of Public Corporation, Harward Business Review, 1989.

14. Monks, R.A.G. i Minow, N.: Corporate Governance, 3rd ed. Oxford Blackwell Publishing, 2003.

15. Omazić, A. M.: Društvena odgovornost i strategije hrvatskih poduzeća, Doktorska disertacije, Ekonomski fakultet, Sveučilište u Zagreb, 2007., pg. 70. - 76.

16. Orsag, S.: Vrijednosni papiri - investicije i instrumenti financiranja, Revicon, Sarajevo, 2011. 
17. Porter, M.E., Montgomery, C.A.: Strategy: Seeking and Securing Competative Adventage, Boston: Harward Business School Press, 1991., pg. 427.

18. Prakash, Sethi, S.: Investing in Socially Responsible Companies is a Must for Public Pension Funds - Because There is no Better Alternative, Journal of Business Ethics 56: pg. 99-129, 2005.

19. Press Briefing: "Industry-wide pension funds all passed performance test" April 2nd, 2004.

20. Salvatore, D.: Ekonomija za menedžere u svjetskoj privredi, Mate, Zagreb, 1994.

21. Santini, I.: Istraživanje pretpostavki primjene shareholdervalue koncepcije u gospodarstvu Republike Hrvatske, magistarski rad, Ekonomski fakultet Zagreb, 2001.

22. Santini, I.: Mikroekonomija, Hibis, Zagreb, 1997.

23. Sikavica, P.: Organizacija, Školska knjiga, Zagreb, 2011.

24. Škrabalo, M., Miošić-Lisjak, N., Bagić, A.: Ubrzanje praksi društveno odgovornog poslovanja, Zagreb, UNDP.

25. Štimac, D., Sopta, M.: Regulatory Framework for Pension Funds, Returns and Risk, 3rd International Conference - An Enterprise Odyssey: Integration or Disintegration, Faculty of Econoics and Business, Zagreb, 2006.

26. Tipurić, D. i suradnici: Korporativno upravljanje, Sinergija, Zagreb, 2008..pg. 340

27. Tipurić, D.: Nadzorni odbor i korporativno upravljanje, Sinergija, Zagreb, 2006. pg.17.

28. Tonks, I.: "Fund Manager Performance of Segregated UK Pension Funds", CMPO, Working Paper Series No. 01/33, University of Bristol

29. World Bank: Economic and Corporate Social Responsibility (EUI radni materijal), European University Institute, 2008.

Web sources:

30. www.hanfa.hr

31. www.mirovinsko.hr

32. http://www.rmf.hr

33. http://www.ersteplavi.hr/default.aspx?ID $=21$

34. Bulletin PBZ-CO mandatory pension fund

35. http://www.pbzco-fond.hr/aboutus/reports2.aspx

36. http://www.azfond.hr/o-nama/az-fondovi

37. http://www.rmf.hr/default.aspx?id=44

38. Narodne novine, 111/93., 34/99., 52/00., 118/03. I 107/07.

39. OECD, Directorate for Financial and Enterprise Affairs "Global Pension Statistics: Assesment of Valuation Methods 


\title{
DRUŠTVENA ODGOVORNOST PODUZEĆA KAO KLJUČNI KRITERIJ ZA ULAGANJE MIROVINSKIH FONDOVA U HRVATSKOJ
}

\author{
Martin Sopta ${ }^{36}$ \& Martina Sopta ${ }^{37}$
}

\begin{abstract}
Sažetak
Snažne promjene u svijetu rada, pritisak ka većoj fleksibilnosti i deregulaciji tržišta rada, sužavaju bazu i obuhvat doprinosa za mirovinsko osiguranje. Duža razdoblja nezaposlenosti i potrage za poslom već su danas gotovo uobičajeni za većinu mladih, a nove tehnologije smanjuju potrebu za ljudskim radom te je posve zamisliva realnost u kojoj gospodarski rast neće ujedno značiti i rast zapošljavanja. U takvim uvjetima, potreba za društvenom solidarnošću i odgovornošću države trebala bi biti veća. Društveno odgovorno poslovanje, posebno područje prava zaposlenika, ovdje se ukazuje kao smjernica za daljnji rast i razvoj poduzeća pri tom vodeći računa o socijalnim, ekološkim i drugim komponentama. Ne smije se zaboraviti niti da je u tom procesu potrebno zadovoljiti ne samo zaposlenike, nego $i$ vlasnike dioničkih društava koji će zasigurno odobravati rast $i$ vrijednost dionica potaknut primjenom fenomena društveno odgovornog poslovanja. $U$ radu se nastoji ukazati na mogućnosti uvažavanja društveno odgovornog poslovanja unutar kriterija odlučivanja prilikom ulaganja obaveznih mirovinskih fondova u Republici Hrvatskoj pošto upravo ona postaju u ovim tržišnim prilikama u mnogim situacijama većinski vlasnici velikih dioničkih društava i time se stvara mogućnost za njihovim presudnim utjecajem kao velikim tržišnim akterima u donošenju odluka u procesu upravljanja vezano za društveno odgovorno poslovanje. Također su u radu prikazani neki primjeri iz prakse mirovinskih fondova iz razvijenih zemalja, te njihovo uključivanje društveno odgovornog poslovanja u glavne tokove funkcioniranja dioničkih društava.
\end{abstract}

Ključne riječi: Hrvatska, ulaganje mirovinskih fondova, društvena odgovornost poduzeća.

JEL klasifikacija: G23

${ }^{36}$ Mr. sc. Martin Sopta, Hrvatska, E-mail: martin.sopta@a3-doo.hr

37 Dr. sc. Martina Sopta, docent, Ekonomski fakultet - Zagreb, Sveučilište u Zagrebu, Hrvatska, E-mail: msopta@efzg.hr 